\title{
The Bible and Akan Traditional Religious Values: A Search For Dialogue
}

\section{Emmanuel Foster Asamoah ${ }^{1}$}

1 Department of Religious Studies, Kwame Nkrumah University of Science and Technology ,Ghana.

\begin{abstract}
In their quest to bring Christianity to Africa in general, and Ghana in particular, the missionaries downplayed and discarded the African traditional religious values. This separated Ghanaians, including Akans from their traditional religious values for the biblical values of the Judeo-Christian scriptures; making them Christians who are cut off from their traditional religious values. After engaging in a dialogue with the biblical values and Akan traditional religious values on a common platform, it was identified that there are basic concepts of commonalities that exist between them, which include common belief in God, family systems, sacrifices, naming ceremonies, prayers, belief in ancestors, etc. and areas of differences which must be refined using the Bible which is seen as the hermeneutics of culture and tradition. This helps to curtail the hypocrisy of many Christians and churches who practise these traditional religious values and provide them with a searchlight to rediscover and modify the elements in their traditional and religious values. In addition, it helps to dispel illusion, remove suspicion and minimise conflict, and to enable the Akans, Ghanaians, or Africans while maintaining their traditional religious values adhere to the teachings of the Bible.
\end{abstract}

Keywords: Bible, biblical values, Akan traditional religious values, and dialogue.

Correspondence:

Emmanuel Foster Asamoah Email: hisdivinegrace7@gmail. com

\section{Manuscript}

Received 23rd June 2020, Accepted 3rd August 2020, Published online 10th August 2020.

(c) 2020 The Author(s). Published and Maintained by Noyam Publishers.

This is an open access article under the CCBY license (http://creativecommons.org/licenses/by/4.0/).

\section{INTRODUCTION}

History has it that Christianity was brought into Ghana (then Gold Coast) in the late fifteenth century by European missionaries. ${ }^{2}$ By the end of the twentieth century, Christianity had gained grounds due to the continuing influx of missionaries. ${ }^{3}$ Before their [the missionaries] coming, Africans in general, and Ghanaians in particular, had their own traditions and religious values which relied on oral transmission. Samuel Fleishacker defines these traditions as "a set of customs passed down over the generations, and a set of beliefs and values endorsing those customs." ${ }^{4}$ These traditions were made up of the Ghanaian traditional religious values received and practiced over the generations. They include, the belief in God; relationship among themselves, their relations and family members; the role of sacrifice in their worship; the observance of naming ceremony and prayers; the belief in ancestors; and their notion for good and evil. But, as it were, the missionaries aside condemning Africa as a "Dark Continent" devoid of civilisation, also gave all sorts of names and derogatory terms ${ }^{5}$, placing no value on and belittling their traditions and religious values. ${ }^{6}$ They [missionaries] replaced these traditions and religious values with biblical values found in the Judeo-Christian scriptures they came with; making Africans to be disassociated from their traditional religious values - not becoming African

\footnotetext{
2 Hans W. Debrunner, A History of Christianity in Ghana, (Accra: Waterville Publishing House, 1967), 17-8; Alfred Koduah, Christianity in Ghana Today, (Accra: Alfred Koduah, 2004), 22.

3 Kofi Asare Opoku, “A Brief History of Independent Church Movements in Ghana since 1862" in The Rise of Independent Churches in Ghana, (Accra: Asempa Publishers, 1990), 7.

4 Samuel Fleishacker, The Ethics of Culture, (Ithaca: Cornel University Press, 1994), 4.

5 Such terms include "animism," "savagery," "paganism," "magic," "fetishism," "idolatry," "juju," "primitive,” and "heathenism”. See; Nana Osei Bonsu, "African Traditional Religion: An Examination of Terminologies Used for Describing the Indigenous Faith of African People, Using an Afrocentric Paradigm," Africology: The Journal of Pan African Studies, 9(9) (Nov. 2016): 108-121.

6 Bonsu, "African Traditional Religion: An Examination of Terminologies Used for Describing the Indigenous Faith of African People, Using an Afrocentric Paradigm," 108-121.
} 


\section{Christians. $^{7}$}

Of late, there has been clarion call for Christians in Africa in general, and Ghana in particular, to have a second look on their traditions and religious values which were looked downed upon some years ago by missionaries, for they form part of their "set of customs passed down over the generations, and [a] set of beliefs and values endorsing those customs." "These traditions also, are their "belief or practice transmitted from one generation to another and accepted as authoritative or deferred to, without argument." It makes it impossible for them to live without them; many Ghanaian Christians and churches are still practising some of these traditional religious values. ${ }^{10}$ In order to curtail this hypocrisy and to provide Ghanaian Christians with a searchlight to rediscover and modify the elements in their tradition and religious values, ${ }^{11}$ there is the need to engage in a dialogue with the Bible and the traditional religious values of the Ghanaians, with the Akans in focus. This will also help to dispel illusion, remove suspicion and minimise conflict. ${ }^{12}$ This study limits itself to the Akans who are part of the larger Ghanaians or Africans for its engagements.

This article seeks to explain what the Bible is and some of its values vis-à-vis the Akan traditional religious values to help engage in the two perspective in the search for the dialogue.

\section{THE BIBLE}

The English word "Bible," comes from biblos in Greek and biblia in Latin meaning "book." Biblios, which initially was the description for the outer coat of the papyrus reed that grew along the Nile River in Egypt around eleventh century B.C., was used in the plural form by the fourth century A.D. by Christians to refer to the Sacred Writings. ${ }^{13}$ The Bible with two main divisions - Old and New Testaments - gives the description of the work of God in the world, and his single-mindedness with all creation. It reveals as a deific love story between God and man who happens to be the object of his love. It gives a description of how the nation Israel was founded, how God chose them to reveal his character and purposes to the world, and how Jesus Christ - the Messiah - from the descendants of King David came to accomplish Israelites expectations and founded the Christian church. ${ }^{14}$ It brings out truth about the creator God, the world and humankind through a series of literary genres to make readers know God individually, revere and serve him. ${ }^{15}$ The book also outlines some principles or values that followers of Jesus Christ hold as important and live by them according to God's directions.

\section{Biblical Values}

Biblical values are the acceptable principles that have been written in the Bible (or Judeo-Christian Scriptures) by individuals under the guidance of the Holy Spirit that followers of Jesus Christ uphold. In effect, they are the godly principles that biblical authors and characters like Moses, Elijah, Isaiah, Daniel, and Jesus Christ taught and practised during their earthly stay. They help Christians to live life to the fullest as God directs. There are many biblical values in the Bible but this article limits itself to the following;

\section{Belief in God}

The Bible tells that there is no God apart from the creator of the heavens and earth. "I, yes I, am the Lord, and there is no other Saviour" (Isaiah 43:11, NLT). "I am the Lord; there is no other God...." (Isaiah 45:5, NLT). "You say you have faith, for you believe that there is one God..." (James 2:19, NLT). There is no other God referred to as Yahweh in the Bible other than the "I AM". He is accessible but invisible to all; no one sees him and lives. In the book of Exodus, the author tells us that "... you may not look directly at my face, for no one may see me [God] and live." (Exo. 33:20, NLT). He is seen as just and fair in all his dealings, and does not like wickedness (Job 8:3). God does not reside in temples made by the hands of man (Acts 7:48; 17:24), though before the advent of Jesus, he initially commanded them to build tabernacles and temples to make him live with the nation Israel. The explanation could be that since he is everywhere it would not be possible to confine him to one place. He must only be worshipped due to his uniqueness. His sovereignty, omniscience, omnipotence, omnipresence, etc. distinguishes him as the only One to be served. Those who worship other gods are referred to as fools, for they give reverence to idol substances that are made by human beings (Ps. 14:1; Isa. 44:9-20). Followers of these inanimate objects are seen as worshippers of creatures than the creator (Rom. 1:25).

\footnotetext{
David T. Adamo, "Christianity and the African traditional religion(s): The postcolonial round of engagement," Verbum et Ecclesia 32(1) (2011): 1-10.

8 Fleishacker, The Ethics of Culture, 4. Peter K. Sarpong is one of such proponents. Read; Peter K. Sarpong, Can Christianity dialogue with African traditional religion? (2006), accessed on December 12, 2017, from https://groups.google.com/forum/m/\#!topic/usaafricadialogue/kuJ0ce--B2g.

H. B. Acton, "Tradition and some other forms of Order," Proceedings of the Aristotelian Society, NS, 53 (1953): 1-28.

10 Adamo, "Christianity and the African traditional religion(s)".

1 John S. Mbiti, Bible and Theology in African Christianity, (Nairobi: Oxford University, 1986), 41.

12 Adamo, "Christianity and the African traditional religion(s)".

3 Roger E. Dickson, Dickson Biblical Research Library, (South Africa: Africa International Missions, 2013$), 15$.

14 Jonathan E. T. Kuwornu-Adjaottor, "Bible Studies and Biblical Studies: An Interface," The Bible, Cultural Identity, and Missions, Edited by Daniel Berchie et. al., (UK: Cambridge Scholars Publishing, 2016), 386-406.

15 J. I. Parker and D. Williams, The Bible Application Handbook, (Guildford, Surrey: Eagle, 1999), 9.
} 
They are recognised as people who believe not in the existence of God.

\section{Family Systems}

Family institution is the basic unit of a society and is ordained by God. The Bible teaches family members to show respect towards each other. Family members must be treated such as honouring one's father and mother in the Lord as a commandment with a promise (Eph. 6:1). The progress of other members in the family is highly cherished by Jesus (Jn. 19:26-27). Family members are not only limited to one's relation but extends to include all who have believed in Jesus Christ and are referred as Christians. Bible admonishes believers to care for fellow Christians (Gal. 6:10) and provide for their needs within ones means. The Bible also teaches the younger family members to take care of their adult family members, as Jesus exemplified on the cross when he handed his mother to John (his disciple).

\section{Sacrifices}

Sacrifice is one of the major themes or values in the Bible. The vast biblical references on sacrifices are found in the Old Testament. Lamb, turtledove, and pigeon are some of the animals used for sacrifice (Lev. 12:6). Sacrifices involved the offering of the blood of these animals. These were used for atonement and cleansing of sins until the coming of Christ Jesus. Since the blood of the animals could not perpetually deal with the sins of the people, it was repeated continuously. However, in the New Testament, the Bible stresses on the need for one to confess their sins and plead for forgiveness, for the blood of Jesus shed on the cross cleanses the sins of humankind eternally without reoccurring. Healing precedes after believing in Jesus Christ, for it is by his [Jesus] stripes, believers are healed. Teachings on the need for one to offer themselves as living sacrifices are also upheld in the Bible, to keep individuals from conforming to the dictates of the ills in the world.

\section{Naming Ceremonies}

According to Albert Doja, names have always established a major feature of people's personhood. ${ }^{16}$ Aside ensuring a personal identity and the consciousness of belonging to a lineage as well as to a community, names also disclose the different possible ties the individual as a person has with the community of his family and kin, and social and natural world assigned to them. ${ }^{17}$ A naming ceremony is to give the child an identity as a member of a particular family. ${ }^{18}$ It is in view of this that names are giving to children in the Bible, for it is one of the important values. Names were given to children eight days after birth (Luke 1:59;2:21). There were times people received names of their children even before they were conceived, i.e. Sampson, John the Baptist and Jesus. Jesus was named on the eighth day when he was circumcised after fulfilling some specific Jewish rituals. According to David Novak, biblical names can indicate a person's character. ${ }^{19} \mathrm{He}$ uses Rinah, a woman's name meaning "song" (or "joy") to explain his point. According to Novak, this name indicates that the bearer is no other person than one who engages in music. ${ }^{20}$ This corroborates with Abigail's description for her husband in the Bible; "Please pay no attention, my lord, to that wicked man Nabal. He is just like his name- - his name means Fool, and folly goes with him..." (1 Sam. 25:25, NIV). Names are usually given to the child by the father. Zachariah gave the name John to his child in writing when he could not speak.

\section{Prayers}

Prayer is the offering of the emotions and desires of the soul to God, in the name and through the mediation of the Lord and Saviour Jesus Christ. Engaging in prayer-personal and communal—are strongly encouraged in the Bible. While personal prayer refers to an individual who engages in personal communication with God, communal prayers are organised by a group of people who are Christians. Personal prayers are organised anywhere and wherever, and communal prayers are organised during church services or any arranged Christian meetings purposed for praying together. Christians, through this prayer, are able to come together for a common good to help the Christian community to be strengthened. Aside giving them strength from on high, prayers are said to fight against the schemes of the devil and his allied forces. The Bible admonishes its users to pray always without ceasing (1 Thess. 5:17).

\section{Belief in Saints}

Saints in this context refer to those who walked blameless life on earth and are now closer to God above. Such people lived in the footstep of Jesus Christ and in accordance to the dictates of biblical teachings. The belief in saints is clearly

\footnotetext{
16 Albert Doja, "Rituals of Naming and Exposure: Meaning and Signification in a Name," Journal of the International Council of Onomastic Sciences, 41 (2006): 237-70.

17 Ibid.

18 Ibid.

19 David Novak, What's in a Jewish Name? Jewish traditions for selecting a child's name, accessed online on July 31 , 2020 from https://www.myjewishlearning. com/article/naming-children/.

20 Ibid.
} 
seen in the Bible. In the Bible, when a person dies, they become part of the great cloud of witnesses who are closer to God in heaven. As they lived blameless life on earth, they are regarded as saints. These heavenly beings have run the heavenly race and obtained the reward of faith, and have entered eternal rest in the LORD. Their existence to a large extent influence believers to put away every weight of sin (or immoral act) that entangles them to live morally well (Heb. 12:1).

\section{Good and Evil}

In the Bible, the existence of good and evil is real and are a common contrast. Good in the Bible reveals the existence of God in the world ${ }^{21}$ for God is the one who brings forth good (Jam. 1:17). On the other hand, evil in the Bible includes physical suffering, ${ }^{22}$ moral evil ${ }^{23}$ and eternal hel1 ${ }^{24} .{ }^{25}$ Opoku Onyinah opines that God, natural or neutral causes, and demons ${ }^{26}$ are presented as the sources of misfortunes (or evil) in the Bible. ${ }^{27}$ The source of evil could also be attributed to the evil or sinful activities of a person. One who commits fornication or adultery is likely to contract a disease when they do not know the status of the person. Aside that they have broken biblical principle of honouring the marriage bed (Heb. 13:4). In the Bible, believers are told to pursue goodness in order to receive God's blessings and not commit evil which leads to destruction (Deut. 28:1-68; 30:15).

\section{AKAN TRADITIONAL RELIGIOUS VALUES}

Ghana, a sub-Saharan West African country, is characterised by multiple indigenous languages, one of such is Akan. As a language, Akan is spoken by the Akan people (or Akans). The Akans form the greater percentage of Ghanaians; about 47.5 percent of the Ghanaian population are Akans. ${ }^{28}$ The Akans are predominantly located in the southern part of Ghana. Their geographical location makes farming, fishing and hunting a conducive occupation for them. With numerous linguistic divisions in Ghana, Akan is spoken in nine out of the sixteen regions in Ghana namely, Ashanti, Eastern, Brong Ahafo, Ahafo, Bono East, Ahafo, Oti, Western, and Central Regions. ${ }^{29}$ The Akan language include Asante-Twi, Akuapem-Twi, Agona, Akyem, Mfantse, Kwahu, Wasa, Assin, Denkyira, Buem, and Bron. These dialects are mutually comprehensible, for a considerable amount of vocabulary are found in them. The Anyi (Aowin), Sefwi, Nzema, Ahanta, Efutu/Awutu, and Anum-Kyerepong-Larteh peoples also speak Akan in addition to their mother-tongue. ${ }^{30}$

The Akan societies share common beliefs, values and practices. This is realised in their language, culture, and worldview. Some differ slightly, but not too distant from each other. These beliefs, values, and practices form part of their traditional values. Using Dale Robbins definition for traditional values for the Americans, Akan traditional religious values could be defined as those acceptable religious standards and values of the Akan people embraced from its earliest beginnings and throughout the majority of their history to practise. ${ }^{31}$ It includes their understanding and practice of family systems, sacrifices, child naming, prayers, and belief in ancestors among others.

\section{The Supreme Being}

Akan traditional religious values portray exact situation for the Supreme Being as depicted in the Bible. According to Akwasi Sarpong, God has a name and there is no question of qualifying that name to apply to another being. ${ }^{32}$ The Supreme Being is seen as the highest level in authority, and identified as "Onyankopon" or "Onyame" in Akan. ${ }^{33}$ Included in his many attributes among the Akans, for example, are: Odomankoma - the infinitely manifold God, ${ }^{34}$ creator, the all grace giver, or he who alone is full of abundance, ${ }^{35}$ Tweduampon - One leans on him with complete

\footnotetext{
21 Dickson, Dickson Biblical Research Library, 1364.

22 This includes suffering such as tornadoes, floods, and deformed babies.

3 This includes suffering such as murder, greed, strife, and lying.

A place of punishment for those who rebel against God.

Dickson, Dickson Biblical Research Library, 1364.

They include Satan, principalities, and other powers in high places.

27 Opoku Onyinah, "Pentecostal Exorcism: Witchcraft and Demonology in Ghana," Journal of Pentecostal Theology Supplement Series (Dorset: Deo Publishing, 2012), 256-7.

28 Ghana Statistical Service, 2010 Population and Housing Census: Summary Report of Final Results, (Accra: Sakoa Press Ltd, 2012$)$, 5.

29 John D. K. Ekem, Priesthood in Context: A Study of Priesthood in Some Christian and Primal Communities of Ghana and its Relevance for Mother-Tongue Biblical Interpretation, (Accra, GH: SonLife Press, 2009), 27; Kofi Agyekum, "The Sociolinguistic of Akan Personal Names," Nordic Journal of African Studies, 15(2) (2006): 206-235.

30 Ekem, Priesthood in Context, 27.

31 Dale A. Robbins, What do they Mean by Traditional Values? Accessed online on July 30, 2020 from https://www.victorious.org/pub/traditional-values-603.

32 Sarpong, Can Christianity dialogue with African traditional religion? (2006), accessed on December 12, 2017, from https://groups.google.com/forum/ $\mathrm{m} / \#$ !topic/usaafricadialogue/kuJ0ce--B2g.

33 Ekem, Priesthood in Context, 32-6; Onyinah, "Pentecostal Exorcism: Witchcraft and Demonology in Ghana," 31-3.

34 Leo Andoh Korsah and Jonathan E. T. Kuwornu-Adjaottor, "The Akan experience of god through the eyes of the Fante from Oguaa," Arts and Humanities Open Access Journal, 3(6) (2019): 280-3.

35 Onyinah, "Pentecostal Exorcism: Witchcraft and Demonology in Ghana," 32; Joseph Boakye Danquah, The Akan Doctrine of God: A Fragment of Gold Coast Ethics and Religion, Edited by Kwasi A. Dickson, 2nd edition, (London: Frank Cass, 1968), 58-77.
} 
safety $;{ }^{36}$ Borebore - Architect of being, Maker of all things; Amowia - the Giver of Light or Sun; ${ }^{37}$ He is the final arbiter of justice, yet people sins compelled him to withdraw from the world. ${ }^{38}$ This implies that he is remote and transcendent rather than approachable.

The Supreme Being is accessible but invisible to all. This, according to Adubofuor Amankwah ${ }^{39}$ is identified

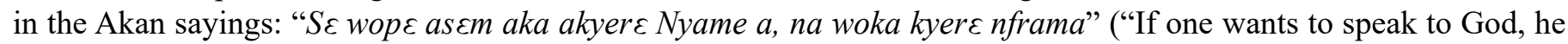
should tell it to the wind"). Akans have the belief that God is of justice and fairness. This is indicated in their maxim that says; "Nyame mp bone nti wama obiara din" ("Since God does not like wickedness, He gave each creature a name").

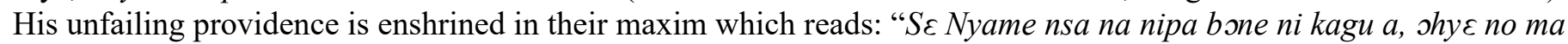
bio" ("If God gives you a cup of wine and an evil-minded person kicks it over, he fills it up again"). God's power over creation is affirmed in their maxim: "Asaase so nanso Nyame ne hene" ("The earth is great but God is chief").

The Supreme Being is everywhere and cannot be confined; hence, he is accessible to all. He enjoys a status immeasurably higher than any other beings. He is the creator of all other beings.

\section{Family Systems}

Akans cherish family systems, for they see themselves as one. They always ensure support is given to their family members at all times. In the Akan family system, members of a family show honour and respect to their fathers and mothers. Aside honouring their biological parents, Ghanaians honour anyone who is eligible to be a father and mother irrespective of whether the individual is known or not. To the Akans, family is a descendant from a common ancestor, and not the make-up of parents and their biological children. This starts from the nuclear and extended family to other families which one do not relate. The Akan family relations extend to comprise a large number of relatives, who are connected by blood bond and trace their descent to a common ancestry. ${ }^{40}$ The culture of how Akans relate with each other as family is broader than the general Western notion of family - the nuclear system. Among the Akans, even when a person is adopted, he is considered as a member of the family, for they help to preserve family lineage, and to ensure care for adoptive parents in their old age. ${ }^{41}$ The relationship between members is guided by the sense of sharing and caring for one another. This is seen in the collective ownership of property such as family lands and houses, although one person might have worked to acquire it, with or without the support of other members. People in a family are not made homeless or without land to work or to fend for themselves in those communities. Unlike the teachings of the Bible where Christians are not to be unequally yoked with unbelievers, family members in the Akan setup share meals from one bowl, irrespective of one's religious and social background. Most of the family members live in one household, usually, within a big enclosed compound.

The traditional family bond brings family members together in the observance of initiation rites, funeral and religious events of family members as well as celebration of cultural festivals by the community as a whole. Akans see the progress in a family member's life as the product of the collective care and nurturing of all the family members as well as of the entire community which portrays a kind of social relationship.

The Akan traditional religious value does not overlook this practice of taking care of their family. As the adage goes, "SE wo papa anaa wo maame hwe wo ma wo se fifi a, hwe won ma won se ntutu" literally translated as "if your father or mother has nurtured and trained you to become fully man with all teeth appearing, look after them for theirs to disappear."

\section{Sacrifices}

Among the Akans, the need for one to confess their sins and plead for forgiveness, is upheld. Opoku Onyinah reveals that, for forgiveness to be upheld, the offender must go through what is known as mmusuo yie- the performance of rituals for propitiation and asking of forgiveness of sins. ${ }^{42}$ The concept of atoning for the life of a person who has committed evil or sin is observed. Propitiatory sacrifice is one of the major ways by which traditional persons deliver themselves from the effects of evil in the world. David Adamo reveals that animals used in African traditional sacrifices [with Akan inclusive] involve the offering of blood, be it that of a human being, animals or birds. However, depending on the gravity of one's illness as a result of evil or sin committed, a sacrifice of a fowl or sheep is demanded and slaughtered either before or after healing. ${ }^{43}$ This does not precede confession for healing and recovery to be effected. In

\footnotetext{
36 Korsah and Kuwornu-Adjaottor, "The Akan experience of god through the eyes of the Fante from Oguaa," 280-3.

37 Ibid.

38 Onyinah, "Pentecostal Exorcism: Witchcraft and Demonology in Ghana," 33.

39 Adubofuor Amankwah is the Abusuapanin (family head) for Manso Abodom Traditional Area. Their queen mother is one of the stool wives to the occupant of the Golden Stool in the Asante Kingdom.

40 Kwame Gyekye, African Cultural Values: An Introduction, (Accra: Sankofa Publishing Company, 1996), 75.

${ }^{41}$ Rex Osei Sarpong and Chris Mensah-Ankrah, Adoption Practices Fuelling Child Trafficking In Ghana (February 13, 2018), accessed online on August 1, 2020, from http://dx.doi.org/10.2139/ssrn.3123813.

42 Onyinah, "Pentecostal Exorcism: Witchcraft and Demonology in Ghana," 48.

43 Adamo, "Christianity and the African traditional religion(s)".
} 
the traditional religious values of Akans animals are used for cleansing evils and sins perpetuated by individuals.

\section{Child Naming}

Child naming is given much priority in the Akan traditional religious values. To Akans, the birth of a child is an event that comes along with a special joy to the entire community. Customarily, in Akan communities, a new-born child is brought into public view or outdoored a week into his birth. On this occasion, the child receives a name and thereby acquires the status of a true and living person. Certain rituals are performed to symbolically welcome the new-born into the family. The naming ceremony is witnessed to give the child an identity as a member of the family. The name is usually given to the child by the father. The father names the child normally after himself or wife or any family member or relation deemed important who has led an exemplary life. This is done in consultation with the other family members; Akans believe that names given to children have tremendous influence on the child's future life.

Kwasi Konadu gives a description of how naming ceremony is organised among the Akans. To him, at the ceremony, usually, the head of the family performs the ritual. He [the head] deeps his finger into water and alcohol and touches the tongue of the baby with drops of each liquid while mentioning the child's name saying, if you say it is water/alcoholic drink, it should be nothing else but water/alcoholic drink. This symbolically is to teach the child to be truthful - distinguish between truth and falsehood in all his/her spheres of influence. ${ }^{44}$ This is normally concluded with traditional prayers followed by celebrations, involving both families of the husband and wife as well as some members of the community.

\section{Prayers}

The Ghanaian traditions play much emphasis on communal prayers. For the Akans communal prayers is said to Onyankopon (The Supreme Being). This happens in the beginning of every gathering and becomes the last thing to be said after the gathering, including family meetings. Prayers are said at all times and is not limited to only communal gatherings and family meetings. E. Bolaji Idowu in his description of how prayerful Africans particularly Yuroba which is similar to Akans prayer life writes: "Prayers are offered, not only at worship, but also at any time and in any place. People often stop on their way to offer brief prayers; or they may speak their prayers in intimate ways to their divinity, whom they believe to be ever present yet unseen, as they walk along the road or as they are engaged in their work." 45 This description seems to depict how prayerful Akans are. Among the reasons for praying is to have bumper harvest, fruit of the womb, preventing the occurrence of catastrophic events, and for protection against evil. They pray through the pouring of libation.

\section{Belief in Ancestors}

Akans place much prominence on funeral traditions for the dead as it constitutes one of the important rites of passage in life. Akans have the belief that death results in a transition for a person from this earthly life to the world of the spirits or ancestors. ${ }^{46}$ In that understanding, the Akan people believe that death does not put an end to life; it is only perceived as a transition from one existence to the other; making them ancestors. ${ }^{47}$ The belief in the ancestors and their worship is prominent among the Akans; they are believed to be forerunners and elders, and for that reason they grasp their respect. Among the Akans in Ghana, all the dead are not raised to the status of ancestors. To become an ancestor, one must have lived to a ripe old age, lived in an exemplary manner, and done much to enhance the standing and prestige of the family, clan, or ethnic group. Barren women and poor lifestyle of deceased individuals are not considered as ancestors. Ancestors are known as the caretakers of the traditions and customs and ever present with the people in their daily activities, and as such are directly concerned in all the affairs of the family. The main ritual that establishes contact between the living and the ancestors is the pouring of libation. During the pouring out of the wine, names of ancestors are mentioned with requests to them for blessings from God. They are thought to be close to God, so they act as relatives who mediate between human beings and God.

Ancestors enter into a spiritual state after death and since this puts them in close touch with the real essence of things they can see and know more than the living and are therefore in a position to mediate between humans and the Supreme Being. Not all ancestors however serve as mediators between the living and the Supreme Being. It is the good and great ancestors, those who have led exemplary lives, who become "Nananom Nsamanfoo," (the good and great ancestors).

\footnotetext{
${ }_{44}$ Kwasi Konadu, Adinto: Akan Naming and Outdooring Ceremony, accessed online on August 1, 2020, from http://www.afropedea.org/adinto-akan-namingand-outdooring-ceremony.

45 E. Bolaji Idowu, Oludumare: God in Yuroba Belief, (London: Longman, 1962), 117.

46 John Kuada \&Yao Chachah, Ghana: Understanding the People and Their Culture (Accra: Woeli Publishing Services, 1999$), 66$.

a Peter K. Sarpong, Dear Nana: Letters to My Ancestor, (Takoradi: Franciscan Publications, 1998), 13.
} 


\section{Good and Evil}

Included in the religious values of Akans are the existence of good and evil. God is the one who brings forth good, but for Akans, human being causes evil to themselves and others. ${ }^{48}$ Onyinah corroborates that the Akans do not attribute the cause of evil to one personified being, Satan or Devil. Rather, it occurs when there is mmusuo - taboo or sin which is done contrary to the law of the land, God, the gods, ancestors, community or one's neighbour. ${ }^{49}$ Evil in the context of the Akan traditions include both physical and moral evil. Evil concerns any misfortune that befalls an individual or community or any voluntary anti-social behaviour or any infringement of the decrees of God, the deity or the ancestors. ${ }^{50}$ Evil is generally interpreted as the work of evil spirits, witches, sorcerers or evil eye, broken taboos, oaths or even the deity or ancestors.

\section{THE BIBLE AND AKAN TRADITIONAL RELIGIOUS VALUE: A SEARCH FOR DIALOGUE}

Macmillan English Dictionary defines the word "dialogue" as a process in which two people or groups have discussions in order to solve problems. ${ }^{51}$ According to the meaning of dialogue, it is to engage in a discussion between two people by exchanging ideas and opinions. In this context, a dialogue seeks to examine the ideas and opinions between two religious groups through communication - be it verbal or written - to get the understanding of each other through concepts articulated in words to be able to draw a conclusion where there will be mutual influence and peaceful coexistence emanating from the exchanged opinion or belief. ${ }^{52}$ In explaining further, John Ekem adds that practitioners of the two religious traditions are not isolated from one another in normal life situations. ${ }^{53}$

The discourse between the Bible and traditional religious values is a delicate issue and must be handled with much care. The Bible is made up of recipient culture ${ }^{54}$ — culture into which the gospel was received — and traditional values also emanate from the cultural setting of its adherents. These traditional religious values reveal the beliefs and practices of a religious group which its adherents participate. Being the core principles of the people, the Akan traditional religious values guide their daily decision making. Jesus [Christ], the central figure of the Bible to a large extent was guided by the Jewish culture, for he born and bred in it. Despite living as a Jew, Jesus was no stranger to any traditional values and culture. That is to say, there is never a time God has left himself without a witness (Acts 14:17). God has appeared to all men since creation. Debrunner, affirming the sayings of Henri-Philippe Junod believes that God [the Son] has been with Ghanaians before the coming of the missionaries. ${ }^{55}$ This indicates that God has been with each and every cultural group of people in the world including the Akans who form the greater percentage of Ghanaians, ${ }^{56}$ for they form part of the bigger Ghanaian culture.

Adamo reveals the importance of engaging in a religious dialogue to include dispelling illusion, removing suspicion and minimising conflict. ${ }^{57}$ In this regard, engaging in a dialogue between the Bible and the Akan traditional religious values will dispel illusion, remove suspicion and minimise conflict among users of the Bible and the Akans who have some religious that are common to all — belief in God, family system, naming ceremony, belief in ancestors, etc. Mbiti adds that it will help to curtail the hypocrisy among Christians, for most practice them, and to provide them with a searchlight to rediscover and modify the elements in their tradition and religious values. ${ }^{58}$ The step to engage in this dialogue is based on the fact that God has never left himself without a witness (Acts 14:17). Thus, God has appeared to all men since creation. With this reason, all traditional values of a tribe or culture reveal the existence of God and his values in a way.

Using the supremacy of God as an example, an examination of the Bible vis-à-vis the Akan traditional religious values reveal certain characteristics of God that clearly gives the description of God in the Bible; he is accessible but invisible to all, just and fair in his dealings with humankind, and does not live in temples though structures are built for him, and among others are some striking similarities. Since there are basic concepts of commonalities that seems to exist between the Bible and that of Akans, the common platform for discussion will lead to discovering of areas of resemblances, which include common belief in God, family systems, sacrifices, naming ceremonies, prayers, and belief in ancestors, etc.

But in as much as there are similarities in the Bible and the Akan traditional religious values, there are also some

\footnotetext{
48 Adamo, "Christianity and the African traditional religion(s)".

49 Onyinah, "Pentecostal Exorcism: Witchcraft and Demonology in Ghana," 47.

50 Adamo, "Christianity and the African traditional religion(s)".

51 Macmillan English Dictionary for Advanced Learners, Dialogue CD-ROM 2nd Edition (Macmillan Publishers Ltd., 2007).

52 Adamo, "Christianity and the African traditional religion(s)".

53 Ekem, Priesthood in Context, 176.

${ }_{54}$ Laussane Movement, Christian Witness to People of African Traditional Religions (LOP 18), accessed online on July 30, 2020, from https://www.lausanne. org/content/lop/lop-18.

55 Hans W. Debrunner, A History of Christianity in Ghana (Accra: Waterville Publishing House, 1967), 1.

56 Ghana Statistical Service, 2010 Population and Housing Census: Summary Report of Final Results, (Accra: Sakoa Press Ltd, 2012 ), 5.

57 Adamo, "Christianity and the African traditional religion(s)".

58 Mbiti, Bible and Theology in African Christianity, 41.
} 
differences and disparities which call the need for a dialogue. Adamo postulates that it is imperative not to overlook these cultural differences that are expressed in different cultural beliefs if genuine dialogue is to be achieved..$^{59}$ Just to mention one example on sacrifice where ancestors are seen as intermediary between God and humanity. This is not what the Bible teaches. In the Bible, Jesus Christ is the mediator between God and man, and not any other being-be it spiritual or physical. He is the only medium and no one goes to the father, except through him. Another example is the belief in the blood of animals as cleansing agents for sinners in order to be "clean" in the Akan traditional religious values. This is not what the Bible teaches in the New Testament where the blood of Jesus is seen as the only panacea to deal with sin and its effects. Since God has never left himself without a witness, he "led" them into it to enable them understand the magnitude of the vicarious death of Christ and the shedding of his saving blood, for the animals represent Jesus Christ who was crucified on the cross to deal with the sins of humanity.

Again, since traditional religious values differ from culture to culture, or better still not the same among cultures, so is biblical values and the Akan traditional religious values to some extent. This is witnessed in their prayers. Among the Akans, alcoholic beverages like akpeteshie (a locally brewed alcoholic beverage) and schnapps are used in prayers, but this is not what the Bible teaches. In the Bible, prayers are said with or without anointing oil. The object used for both is not the same-akpeteshie and anointing oil. Some biblical characters poured libation in the Old Testament which are traditions of Judaism, ${ }^{60}$ for the Bible is made up of "recipient culture"-culture into which the gospel was received - and traditional values also emanate from the cultural setting of its adherents. However these are not found in the New Testament which is the fulfilment of the Old Testament. In such situations, the Bible which is seen as the hermeneutics of culture and tradition, must be used as the yardstick to refine such traditions. ${ }^{61}$

Engaging in a dialogue with the Bible and Akan traditional religious values will help Akan Christians to understand their religious values in the light of scriptures so that they can hold onto their traditional religious values and not be dissociated from their traditions while practising Christianity. In as much as the early Christians held on their traditional religious values in the light of the biblical values, so Akan [Ghanaians or African] Christians can do likewise.

\section{CONCLUSION}

From the discussions so far, the need to have a dialogue with the biblical principles and Akan traditional religious values is very important. It is said that man is a cultural animal who needs to worship the Supreme Being and adhere to their religious values which are to be in line with biblical values. Since all cultures have traditions that are considered both good and bad, there is the need to have a dialogue of the Bible with the traditions. This will make the traditional religious values of the Akans well discovered and make it "more refined" to reflect biblical values which are the standard godly living for Christians. This makes Akans, whiles maintaining their culture, serve the Supreme Being; thereby, making them become Akan Christians, rather than being Christians in Akan community.

\section{BIBLIOGRAPHY}

Acton, H. B. "Tradition and some other forms of Order," Proceedings of the Aristotelian Society, NS, 53 (1953): 1-28.

Adamo, David T. "Christianity and the African traditional religion(s): The postcolonial round of engagement," Verbum et Ecclesia 32(1) (2011): 1-10.

Agyekum, Kofi, “The Sociolinguistic of Akan Personal Names," Nordic Journal of African Studies, 15(2) (2006): 206-235.

Bediako, Kwame, "Scripture as the hermeneutic of culture and tradition," Journal of African Christian Thought, 4(1) (2001): 2-11.

Bonsu, Nana Osei, “African Traditional Religion: An Examination of Terminologies Used for Describing the Indigenous Faith of African People, Using an Afrocentric Paradigm," Africology: The Journal of Pan African Studies, 9(9) (Nov. 2016): 108-121.

Danquah, Joseph Boakye, The Akan Doctrine of God: A Fragment of Gold Coast Ethics and Religion. Edited by

Kwasi A. Dickson, 2nd edition. London: Frank Cass, 1968.

Debrunner, Hans W. A History of Christianity in Ghana. Accra: Waterville Publishing House, 1967.

Dickson, Roger E. Dickson Biblical Research Library. South Africa: Africa International Missions, 2013.

Doja, Albert, "Rituals of Naming and Exposure: Meaning and Signification in a Name," Journal of the International Council of Onomastic Sciences, 41 (2006): 237-70.

\footnotetext{
59 Adamo, "Christianity and the African traditional religion(s)".

60 This refers to the religion of the Jews (or Jewish), who trace their ancestry to Abraham, Moses and the Hebrew prophets. Judaism centres more on observing rituals, doing good deeds and studying traditions.

${ }^{61}$ Kwame Bediako, "Scripture as the hermeneutic of culture and tradition," Journal of African Christian Thought, 4(1) (2001): 2-11.
} 
Ekem, John D. K. Priesthood in Context: A Study of Priesthood in Some Christian and Primal Communities of Ghana and its Relevance for Mother-Tongue Biblical Interpretation. Accra, GH: SonLife Press, 2009.

Fleishacker, Samuel, The Ethics of Culture. Ithaca: Cornel University Press, 1994.

Ghana Statistical Service, 2010 Population and Housing Census: Summary Report of Final Results. Accra: Sakoa Press Ltd, 2012.

Gyekye, Kwame African Cultural Values: An Introduction. Accra: Sankofa Publishing Company, 1996.

Idowu, E. Bolaji, Oludumare: God in Yuroba Belief. London: Longman, 1962.

Koduah, Alfred, Christianity in Ghana Today. Accra: Alfred Koduah, 2004.

Konadu, Kwasi, Adinto: Akan Naming and Outdooring Ceremony. Accessed online on August 1, 2020, from http:// www.afropedea.org/adinto-akan-naming-and-outdooring-ceremony.

Korsah, Leo Andoh and Jonathan E. T. Kuwornu-Adjaottor, "The Akan experience of god through the eyes of the Fante from Oguaa," Arts and Humanities Open Access Journal, 3(6) (2019): 280-3.

Kuada, John \&Yao Chachah, Ghana: Understanding the People and Their Culture. Accra: Woeli Publishing Services, 1999.

Kuwornu-Adjaottor, Jonathan E. T. "Bible Studies and Biblical Studies: An Interface," The Bible, Cultural Identity, and Missions, Edited by Daniel Berchie et. al., (UK: Cambridge Scholars Publishing, 2016), 386-406.

Laussane Movement, Christian Witness to People of African Traditional Religions (LOP 18). Accessed online on July 30, 2020, from https://www.lausanne.org/content/lop/lop-18.

Macmillan English Dictionary for Advanced Learners, Dialogue CD-ROM 2nd Edition. Macmillan Publishers Ltd., 2007.

Mbiti, John S. Bible and Theology in African Christianity. Nairobi: Oxford University, 1986.

Novak, David, What's in a Jewish Name? Jewish traditions for selecting a child's name, accessed online on July 31 , 2020 from https://www.myjewishlearning.com/article/naming-children/.

Onyinah, Opoku, "Pentecostal Exorcism: Witchcraft and Demonology in Ghana," Journal of Pentecostal Theology Supplement Series (Dorset: Deo Publishing, 2012), 256-7.

Opoku, Kofi Asare, “A Brief History of Independent Church Movements in Ghana since 1862" in The Rise of Independent Churches in Ghana. Accra: Asempa Publishers, 1990.

Parker, J. I. and D. Williams, The Bible Application Handbook. Guildford, Surrey: Eagle, 1999.

Robbins, Dale A. What do they Mean by Traditional Values? Accessed online on July 30, 2020 from https://www. victorious.org/pub/traditional-values-603.

Sarpong, Peter K. Can Christianity dialogue with African traditional religion? (2006). Accessed on December 12, 2017, from https://groups.google.com/forum/m/\#!topic/usaafricadialogue/kuJ0ce--B2g.

Sarpong, Peter K. Dear Nana: Letters to My Ancestor. Takoradi: Franciscan Publications, 1998.

Sarpong, Rex Osei and Chris Mensah-Ankrah, Adoption Practices Fuelling Child Trafficking In Ghana (February 13, 2018). Accessed online on August 1, 2020, from http://dx.doi.org/10.2139/ssrn.3123813

\footnotetext{
ABOUT AUTHOR

Emmanuel Foster Asamoah, BTh, MPhil, Research Associate, Department of Religious Studies, Kwame Nkrumah University of Science and Technology, Kumasi. He is an ordained minister of The Church of Pentecost, pastoring at Antoakrom, Ashanti Region, Ghana. His areas of interest are Biblical Studies, Bible Translations, Mother-tongue Biblical Hermeneutics, and Biblical Apocalyptic Literature.
} 